DOI 10.4467/2543733XSSB.19.010.11409

MAŁGORZATA ABASSY

Uniwersytet Jagielloński

\title{
OBRAZ ROSJI I ROSJAN \\ W KRAKOWSKIEJ PRASIE 1918 ROKU. PERSPEKTYWA KULTUROWA: KODOWANIE - DEKODOWANIE I RE-KODOWANIE
}

\author{
The Image of Russia and Russians \\ in the Krakow Press in 1918. \\ A Cultural Perspective: Encoding - \\ Decoding and Re-coding
}

Summary

The years of dependence fixed a specific picture of Russia and the Russians. This was conditioned by enmity against the invaders on the one hand and - by the need of auto-creation and painting a positive picture by the very czarist Russia, on the other hand. Newspapers, as opinion-forming tools, became a stage for the struggle between such a creation of the image of the world in which Russia had a positive and prevalent role, and such forming the image in which freedom and patriotism were of fundamental significance.

The year 1918 brought significant changes due to the fact that the qualities of the eastern neighbor were being transformed. The resurgent Poland created its identity upon the basis of the endogenous components which were known in advance, such as: independence, honor and freedom and struggle for it; and also by referring to the exogenous ones. The new Russia was one of them.

A cultural perspective has been adopted in this paper. The applied methodology would help to reveal the mechanisms typical for a culture at the moment of sudden changes: to unveil the hidden codes, to confront their contents with the declared ones (official) and re-coding. The latter one is necessary to enable the culture to absorb or reject cultural influence from the neighbor who has changed some of its cultural patterns.

Keywords: Poland - Russia - newspapers - culture - cultural codes

Słowa kluczowe: Polska - Rosja - prasa - kultura - kody kulturowe 


\section{Przesłanki podjęcia tematu: jego aktualność}

Tożsamość państwowa, postrzegana przez pryzmat jego interesów na arenie międzynarodowej, jest jednym z najbardziej aktualnych tematów, podejmowanych przez elity społeczne ${ }^{1}$. Będąc fenomenem niezwykle dynamicznym, nabiera ostrości nie tylko jako problem badawczy, ale także jako przedmiot dyskusji dnia powszedniego. W tym drugim przypadku tożsamość państwowa i, powiązana z nią implicite, tożsamość narodowa stają się przedmiotem stereotypowych, a w najlepszym przypadku, ogólnych ujęć. „Obcy” jako punkt odniesienia do kształtowania i potwierdzenia tożsamości zyskuje szczególne znaczenie, gdy na pewnym poziomie wykazuje cechy wspólne z tym, co „swoje”, na przykład słowiańskość, będąc zdecydowanym antagonistą na innym poziomie - na przykład ustroju politycznego i stylu sprawowania rządów. Wydarzenia historyczne oraz ich okragłe rocznice skłaniają do refleksji nad mechanizmami konstruowania wizerunku „obcego”, w tym przypadku Rosji, by potwierdzić własną tożsamość państwową i narodową. Setna rocznica odzyskania przez Polskę niepodległości stanowi przypomnienie o innych wydarzeniach historycznych: rewolucji październikowej 1917 roku oraz idącymi w ślad za tym zmianami o charakterze kulturowym, których manifestacją łatwiejszą do uchwycenia i badania, były przemiany polityczne i społeczne. Próba sięgnięcia do teorii mechanizmów rozwoju kultury daje możliwość opisu zjawisk o dłuższym okresie trwania niż kilka lat, obejmujących okres burzliwych przemian. Re-kodowanie kultury, polegające na odrzuceniu istniejących wyobrażeń na temat Rosji i przyjęciu nowych, to proces, który ma na celu dostarczenie społeczeństwu spójnego, chociaż uproszczonego, zbioru wzorów myślenia o „obcym”.

\section{Cele i hipotezy badawcze}

Celem niniejszego artykułu jest zbadanie, w jaki sposób rewolucja październikowa i jej bezpośrednie skutki, będące rezultatem trwającego co najmniej od lat 60. XIX wieku kryzysu Rosji carskiej, wpływały na kształtowanie się obrazu Rosji i Rosjan w rodzącej się, niepodległej Polsce, wspierając tym samym budowanie jej tożsamości.

Punktem wyjścia do rozważań stała się obserwacja, będąca zarazem hipotezą badawczą, iż wizerunek Rosji zmienia się w momencie sytuacji kryzysowych dla państwa polskiego: gdy musi ono walczyć o swoją niezależność, realną, a nie tylko formalną, na arenie międzynarodowej, zmagając się jednocześnie z koniecznością wyboru jednej z dróg rozwoju i opcji politycznych w sprawach wewnętrznych. Hipotezę pomocniczą stanowi stwierdzenie, iż Rosja, co najmniej od czasów carycy Katarzyny II, stanowiła dla Polski punkt odniesienia do kształtowania tożsamości narodowej. Będąc zaborca, stymulowała walkę o zachowanie wartości składających się na ,polskość” jako pojęcie, przeczucie i działanie. Zbiór czynów, symboli i leżących u ich podstaw wartości będziemy nazywać kodem. Podstawowe kody zamknięto w triadzie: Bóg - Honor - Ojczyzna. Były one wyrazem identyfikacji z katolicyzmem, narodową dumą stanowiącą imperatyw walki o wolność, patriotyzmem. $Z$ tego punktu widzenia dokonywano re-kodowania wzorów, które składały się na wyobrażenie Rosji i Rosjan.

\footnotetext{
${ }^{1}$ Por. W. Bloom, Personal Identity, National Identity and International Relations, Cambridge 1990, s. $25-53$.
} 


\section{Charakterystyka materiału źródłowego. Zasady doboru tekstów}

Dobór materiału źródłowego został dokonany w procesie analizy treści krakowskich dzienników, wychodzących w roku 1918. Przegląd poszczególnych tytułów pozwolił zidentyfikować reprezentowany światopogląd i postawy ideowe promowane przez dany tytuł, zawartość poszczególnych numerów, częstotliwość ukazywania się, nakład, zasięg, typ przeciętnego odbiorcy, czas obecności na rynku wydawniczym. Pod uwagę brano dzienniki wychodzące w Krakowie. Za takim wyborem przemawiał fakt, że Kraków był stosunkowo niezależny od carskiej cenzury, chociaż podlegał regulacjom obowiązującym w Galicji, jeśli chodzi o politykę wydawniczą. Ponadto był on miastem kojarzonym z życiem kulturalnym, a przy tym bardziej odpornym na koniunkturę polityczną niż Warszawa, co w przypadku badania kodów kulturowych ma znaczenie zasadnicze. Prasę krakowską wybrano również z tego względu, że to właśnie w Galicji dochodziło do krzyżowania się i dialogu różnych wpływów kulturowych w stopniu niespotykanym w innych zaborach $^{2}$.

W interesującym nas okresie w Krakowie wychodziło siedem dzienników: „Czas”, „Nowa Reforma”, „Naprzód”, „Głos Narodu”, „Ilustrowany Kurier Codzienny”, „Gazeta Krakowska”, „Goniec Krakowski”. Najstarszy z nich, „Czas”, reprezentował stanowisko konserwatywne ${ }^{4}$. Wychodził w Krakowie od 1848 roku, zaś właścicielami drukarni był ród Potockich z Łańcuta. Drugi, w kolejności chronologicznej, dziennik to „Nowa Reforma” (pod tym tytułem wychodząca od 1882 roku), będąca pismem demokratów ${ }^{5}$. W 1892 roku ukazał się pierwszy numer czasopisma Polskiej Partii Socjalno-Demokratycznej, „Naprzód”. Dziennik prezentował program socjalistyczny i, jak zauważył badacz krakowskiej prasy, Józef Seniów:

Tworzył on legendę I Brygady Legionów Polskich i jej dowódcy Józefa Piłsudskiego, uznawanego za postać wybitną. Nie bez znaczenia dla „Naprzodu” była jego przynależność do partii socjalistycznej, dla rozwoju której szczególnie się zasłużył

Rok później niż „Naprzód” powstał „Głos Narodu”, prezentujący poglądy chrześcijańsko-demokratyczne? ${ }^{7}$.

„Ilustrowany Kurier Codzienny” („IKC”) stanowi na ich tle zjawisko o tyle ciekawe, że pozostawał - zarówno w świetle deklaracji jego twórców i wydawców, jak też w opinii badaczy - dziennikiem niezwiązanym z konkretną opcją polityczną ${ }^{8}$. Fakt ten umożliwiał mu dotarcie do szerszego grona odbiorców aniżeli tylko sympatycy jednej partii czy okre-

\footnotetext{
${ }^{2}$ Por. D. Sosnowska, Inna Galicja, Warszawa 2008, s. 14-17.

${ }^{3}$ J. M. Seniów, Prasa krakowska w czasie pierwszej wojny światowej (1914-1918), „Zeszyty Prasoznawcze”, r. XLV, nr 3-4, s. 120-136. Por. także J. Myśliński, Studia nad polska prasq spoteczno-politycznq w Zachodniej Galicji 1905-1914, „Materiały i Studia do Historii Prasy i Czasopiśmiennictwa Polskiego”, z. 16, Warszawa 1970.

${ }^{4}$ J.M. Seniów, Na drodze do niepodleglości. Prasa krakowska wobec Legionów Polskich podczas I wojny światowej (1914-1918), Kraków 2004, s. 20.

${ }^{5}$ Ibidem, s. 23.

${ }^{6}$ Ibidem, s. 25.

${ }^{7}$ Ibidem, s. 25. Por. także C. Lechicki, Krakowski „, Gtos Narodu” w latach 1914-1939, „Studia Historyczne", Wrocław 1973, s. 343-361.

${ }^{8}$ Por. Cz. Brzoza, Polityczna prasa krakowska 1918-1939, Kraków 1990, s. 138.
} 
ślonego światopoglądu. Został założony w 1910 roku i w krótkim czasie stał się najpopularniejszym dziennikiem krakowskim. Jak zauważył Czesław Brzoza:

Tajemnica jego powodzenia polegała przede wszystkim na nowatorskim sposobie redagowania, podkreślaniu nie tylko wielkich wydarzeń politycznych, komentowanych i tak szeroko przez pozostałe wydawnictwa, ale ukazywaniu na pierwszym miejscu spraw często mało istotnych, niemniej jednak budzących duże zainteresowanie. (...) Inaczej niż w pozostałych dziennikach wyglądał też dział miejski. Te same wiadomości, które w „Czasie”, „Nowej Reformie” czy „Naprzodzie” znajdowały odbicie wyłącznie w kronice, w „IKC” urastały do rangi samodzielnych, opatrzonych dużymi tytułami artykułów. Każdemu wydarzeniu starano się nadać wydźwięk sensacji ${ }^{9}$.

Niewyszukany język, ujęcie wydarzeń w formie sensacji, a zatem przyobleczenie ich w intrygująca, budzącą zaciekawienie szatę przysparzało „IKC” czytelników. Popularność dziennika podsycało również odwoływanie się do spraw lokalnych, miejskich, które były o wiele bliższe i bardziej zrozumiałe dla przeciętnego, o niewyrobionych gustach czytelnika niż wiadomości o wydarzeniach międzynarodowych. Te drugie również czytano, niejako ,przy okazji”, i ten fakt sprawiał, że gazeta stanowiła jedno z najbardziej skutecznych narzędzi kształtowania i rozpowszechniania wizerunku Rosji.

Reasumując, brak afiliacji z opcją polityczną oraz ciekawy, balansujący na granicy sensacji, sposób prezentowania treści wpływał pozytywnie na liczbę czytelników. Przytoczone argumenty sprawiły, iż uznaliśmy „IKC” za dziennik reprezentatywny dla dociekań o tendencjach w re-kodowaniu obrazu Rosji i Rosjan w świadomości kulturowej mieszkańców Krakowa w 1918 roku.

Analizie zostały poddane treści artykułów „ICK”, wychodzące od stycznia do grudnia 1918 roku.

\section{Metodologia badań}

Za podstawowe narzędzie metodologiczne została przyjęta metoda semiotyczna, traktująca kulturę i jej przestrzeń jako obszar komunikowania się znaczeń za pośrednictwem kodów, składających się ze znaków i symboli ${ }^{10}$. W analizach uwzględniono jeden tylko typ kodu: słowo wraz z jego semantyką, wyrażaną explicite bądź poprzez konteksty. Pierwszy etap dociekań metodologicznych obejmował definiowanie treści pojęcia „Rosja”. Uznano, że oznacza ono Rosję carską, czyli taką, jaka kojarzyła się Polakom z czasami zaborów. Kolejny etap badań prowadził do wyłonienia słów bliskoznacznych i odrzucenia tych, które były kojarzone z Rosją, lecz nie odnosiły się do jej istoty i w roku 1918 nie stanowiły immanentnej komponenty pojęcia „Rosja”. W tej fazie dociekań wyłoniła się konkluzja, iż nie istniał w krakowskiej prasie obraz Rosjanina jako takiego. Można mówić natomiast o portrecie zbiorowym, utożsamionym z Rosją. Nawet w przypadku opisów losów rodziny carskiej i cara Mikołaja III postać władcy należy odczytywać jako symbol Rosji.

\footnotetext{
${ }^{9}$ Ibidem, s. 126.

${ }^{10}$ Szerzej: B. Żyłko, Semiotyka. Szkoła tartusko-moskiewska, Gdańsk 2009; J.J. Jadacki, Metodologia i semiotyka: idee - metody - problemy, Warszawa 2010.
} 
Słowo „Rosja”, obecne w artykułach, zostało potraktowane jako przesłanka do wnikliwej analizy treści tekstu. Na tym etapie dociekań dokonano posegregowania artykułów według stopnia uwagi, jaką przyciągały. I tak, pierwszeństwo dano artykułom, które miały w tytule słowo „Rosja” i znajdowały się na pierwszej stronie numeru „IKC”. Drugie miejsce zajęł artykuły posiadające słowo „Rosja” w tytule, lecz znajdujące się na dalszych stronach numeru. Następnie poddano analizie teksty zawierające słowo „Rosja” lub jedno ze słów bliskoznacznych, jak na przykład „Moskwa”, „Petersburg”, „carski”, „,bolszewizm”. Ostatni, czwarty korpus analizowanych tekstów stworzyły te, które podejmowały tematy pokrewne. Stanowią one niewielki przyczynek do odtworzenia obrazu Rosji i Rosjanina, dlatego w ostatecznym omówieniu zostały pominięte.

\section{Kontekst ideowo-historyczny}

Rosja istniała w polskiej świadomości politycznej i społecznej jako zaborca, rusyfikator i jeden ze strażników Świętego Przymierza, zawartego na kongresie wiedeńskim w 1815 roku. Losy Polski były przedmiotem rozgrywek między trzema mocarstwami i fakt ten nie stracił na znaczeniu również w roku odzyskania niepodległości. „IKC” zamieścił wiersz, który śmieszył jedynie na pierwszy rzut oka:

Nie tak dawno, bo w tym roku

Osaczona przez psy skrycie

Mała sarna ze łzą w oku

Słucha targów o swe życie.

W końcu przecież - z tremą w głosie

Gdy psia rada tak rozprawia -

Jeden rzecze: O swym losie

Sama sarna postanawia.

„Chcę wolności” - rzeknie mała.

„Co to - to nie! Chodzi właśnie,

Ażebyś nas zrozumiała.

Zaraz tobie to wyjaśnię".

I wyjaśnia - stojąc przed nią,

By wykazać trud jej marny.

„Chodzi o to czy Wać Panią

Ma zjeść biały pies czy czarny" ${ }^{11}$.

Antypolska polityka caratu zmieniła się w czasie I wojny światowej, gdy w niemieckiej i austro-węgierskiej deklaracji z 5 listopada 1916 roku znalazła się zapowiedź odbudowania Królestwa Polskiego z ziem odebranych Rosji ${ }^{12}$. W odpowiedzi na tę deklarację car

\footnotetext{
${ }^{11}$ Bajka, „Ilustrowany Kurier Codzienny” (dalej „IKC”), 22 stycznia 1918, nr 22, s. 3.

${ }^{12}$ H. Jankowska, T. Jędruszczak (red.), Powstanie II Rzeczypospolitej. Wybór dokumentów 1886-1925, Warszawa 1981, s. 223-224.
} 
Mikołaj II obiecał „odbudowanie Polski, złożonej z trzech dotychczas rozdzielonych części"'13. Niemniej jednak istotna zmiana kierunku polityki rosyjskiej wobec ziem polskich zaszła dopiero po upadku caratu, gdy nowe władze - bolszewickie - zobowiązały się do zdecydowanego odrzucenia polityki Rosji carskiej. Piotrogrodzka Rada Delegatów Robotniczych i Żołnierskich (Петроградский совет рабочих и солдатских депутатов) 27 marca 1917 roku oświadczyła, że ,demokracja w Rosji stoi na stanowisku uznania samookreślenia politycznego narodu i oznajmia, że Polska ma prawo do całkowitej niepodległości pod względem państwowo-międzynarodowym"14, zaś Rząd Tymczasowy Rosji (Временное правительство России) w uchwalonym 29 marca 1917 roku manifeście głosił, że:

Naród rosyjski, który zrzucił jarzmo, przyznaje także polskiemu bratniemu narodowi pełne prawo samostanowienia o własnym losie według własnej woli (....) i dopomoże w utworzeniu niezawisłego państwa polskiego ze wszystkich terytoriów, w których Polacy tworzą większość, jako rękojmi trwałego pokoju w przyszłej, nowo zorganizowanej Europie ${ }^{15}$.

W listopadzie 1918 roku ostatecznie rozpadł się porządek polityczny Europy, gdy w ślad za Rosją, wojnę przegrały Niemcy i Austro-Węgry. Zmieniający się porządek polityczny, pociągał za sobą niepokoje zwykłego obywatela o własną przyszłość w odradzającej się ojczyźnie. Nie do końca rozumiejąc istotę rozgrywek politycznych i napięcie między dwoma stronnictwami: proaustriackim, reprezentowanym przez Józefa Piłsudskiego i prorosyjskim, którego centralną postacią był Roman Dmowski, przeciętny Polak chłonął tworzącą się „legendę Legionów” i próbował wyobrazić sobie nową Rosję. Jednocześnie gazety codzienne dostarczały mu wiadomości na temat rozgrywek upadających europejskich potęg, z których każda zaczęła doceniać rolę Polski w rodzącym się porządku. Jak zauważył niemiecki historyk, Klaus Zernack:

Wojna między dawnymi sprzymierzeńcami tocząca się na terytorium podzielonej Polski pomogła temu krajowi zająć kluczową pozycję w toku wydarzeń. Zasady rosyjskiej, a także niemieckiej i austriackiej polityki wobec Polski należycie uwzględniały tę okoliczność jeszcze na długo przed wybuchem konfliktu zbrojnego. Wiedziano, że będzie to wojna o Polskę i za Polskę (podkreślenie moje - M.A.) ${ }^{16}$.

W nowym porządku Europy rola Rosji nadal była przez Polaków postrzegana jako fundamentalna, dlatego też wyobrażenie sobie tego nowego tworu politycznego oraz kulturowego przez pryzmat niskich i średnich warstw społecznych, przejmujących ster władzy, było zadaniem dosyć istotnym. Prasa codzienna, w tym „IKC”, spełniała zadanie dostarczania Polakom informacji, na podstawie których mogli tworzyć wyobrażenie Rosji i Rosjanina u progu nowej epoki historycznej.

${ }^{13}$ Ibidem, s. 317.

${ }^{14}$ W. Gostyńska (oprac.), Dokumenty i materiaty do historii stosunków polsko-radzieckich, t. 1, marzec 1917- listopad 1918, Warszawa 1962, s. 8.

${ }^{15}$ Ibidem, s. 19.

${ }^{16}$ K. Zernack, Polska i Rosja. Dwie drogi w dziejach Europy, A. Kopacki (przeł.), Warszawa 2000, s. $480-481$. 


\section{Obraz Rosji i Rosjanina w artykułach „IKC”}

Dekodowanie i re-kodowanie obrazu Rosji i Rosjanina koncentrowało się wokół dwóch zasadniczych tematów: rodzącej się Rosji bolszewickiej wraz z całym spektrum powiązanych z tym faktem kwestii oraz pozycji Rosji na arenie międzynarodowej w negocjacjach i sporach z państwami europejskimi przez pryzmat losów Polski, a zwłaszcza jej prawa do samostanowienia i integralności terytorialnej.

Artykuły na pierwszych stronach dotyczyły głównie problemów związanych z tematem drugim - położeniem Rosji w skomplikowanym układzie państw europejskich w czasie I wojny światowej. Rzadziej zamieszczano teksty traktujące o bolszewizmie, a jeśli już one się pojawiały, to miały raczej charakter informacyjny niż modelujący, to znaczy skłaniający czytelnika do przyjęcia określonego schematu interpretacji wydarzeń. Najwięcej tego typu artykułów: odnoszących się do działań wojennych, rokowań pokojowych w Brześciu Litewskim, współzależności i rywalizacji między państwami centralnymi a Rosją znajdziemy w numerach „IKC” z pierwszego kwartału 1918 roku. Od czerwca tegoż roku, czyli kwartału trzeciego ${ }^{17}$, pierwsze strony poszczególnych wydań zajmują przede wszystkim artykuły i notki dotyczące bolszewizmu jako zjawiska politycznego i historycznego. Chociaż zagadnienie napięć między Rosją a Niemcami nie znika zupełnie, to redaktorzy dziennika przyznają mu o wiele mniej miejsca na łamach czasopisma niż na początku roku. Podpisanie pokoju w Brześciu, 3 marca 1918 roku przesunęło punkt ciężkości w namyśle nad zależnościami polsko-rosyjskimi w stronę istoty i przyszłości bolszewizmu.

Począwszy od sierpnia 1918 roku, zainteresowanie wspomnianymi wyżej wątkami wygasa, co znalazło odzwierciedlenie zarówno w artykułach zamieszczanych na pierwszych stronach poszczególnych numerów „IKC”, jak też tych na dalszych stronach i w formie krótkich notek. Czytelnik dziennika dowiaduje się o zmianach w bolszewickiej Rosji, nie są to jednak wątki nowe. Pojawiają się też nieliczne artykuły o charakterze kulturowym, stanowiące refleksję nad przyczynami i istotą bolszewizmu oraz dające wyraz nadziei, że zjawisko to przeminie bezpowrotnie.

Temat Rosji i Rosjan pod koniec roku pojawia się na łamach „IKC” sporadycznie, ustępując miejsca zagadnieniom związanym z tworzeniem struktur II Rzeczypospolitej.

Jak zostało wspomniane wyżej, najbardziej liczny korpus tekstów dotyczących Rosji i zamieszczonych na pierwszych stronach dziennika odnosi się do początku 1918 roku i obejmuje problem prawa do samostanowienia: poczynając od granic, przez ustrój polityczny, po relacje z innymi państwami.

Dnia 1 stycznia 1918 roku na pierwszej stronie pojawił się artykuł: Państwa centralne nie mogq zerwać z Rosja. W tekście poruszono kwestię wpływu Rosji na kształt polityczny państwa polskiego i jego rolę w utrzymaniu równowagi między krajami zachodnimi a Rosją. Powstająca nowa Rosja jawi się jako obrońca prawa Polski (a obok niej Litwy i Kurlandii) do samostanowienia, będąc zarazem w pułapce swoich wcześniejszych deklaracji:

${ }^{17}$ Przez okres od marca do czerwca 1918 roku dziennik się nie ukazywał. Jego działalność została zawieszona 15 marca 1918 roku, o czym informuje czytelnika notka z dnia 15 marca tegoż roku z 73 numeru „IKC”; o wznowieniu działalności znajdziemy informację w postaci artykułu na pierwszej stronie dziennika $\mathrm{z}$ dn. 19 czerwca 1918 roku. 
Gdyby Rosja została pod tym względem wywiedziona w pole, to grozi jej samej krwawa kontrrewolucja żywiołów szowinistycznych, które wskazałyby obudzonemu narodowi, że Rosja straciła trzy najludniejsze kraje nie na rzecz narodów zamieszkujących je, a na rzecz podstępnie działającego zaborcy ${ }^{18}$.

Artykuł nadaje ton całemu numerowi, co można wywnioskować po tytułach na kolejnych stronach wydania: Francusko-angielskie intrygi w Rosji. O przetrzymaniu do wiosny, Porozumienie misji angielskiej z rzadem rosyjskim, Pod polskie panowanie ne pidemo. Ukraińcy za przyłaczeniem Galicji wschodniej do sfederowanej z Rosja republiki ukraińskiej $^{19}$.

Słowa „Polska” i „Rosja” stanowią klucz porządkujący główne treści numeru trzeciego „IKC”. Na pierwszej stronie znajdują się dwa artykuły: Pokój z Rosja żywotnym zagadnieniem państw centralnych oraz Polska nie potrzebuje pożyczać od Rosji pojęć wolnościowych. Sensacyjny list pod adresem bolszewickiej „,Prawdy”. Pierwszy jest omówieniem tekstu wydrukowanego w niemieckim „Freie Presse”. Podkreślono w nim, że w obliczu wojny z Ameryką i Anglią Niemcy potrzebują zachować dobre stosunki z Rosją. Drugi, utrzymany w tonie ironicznym, stanowi zawoalowaną krytykę idei bolszewizmu oraz podaje w wątpliwość szczerość intencji jego reprezentantów. Ze względu na ton, w jakim jest utrzymany, oraz na główny wątek tematyczny, wskazujący na to, iż idee wolności i braterstwa nie są, ,wynalazkiem” bolszewików, artykuł dostarcza czytelnikowi narzędzia do interpretacji zjawiska, które nieodłącznie wiąże się z nową Rosją oraz z charakterem wywieranych przez nią wpływów. Tekst zaczyna się na pierwszej stronie numeru gazety i ma swój dalszy ciąg na kolejnej. Sąsiaduje z nim inny, zawierający formę słowa „bolszewik": Zatarg z bolszewikami o wojsko polskie. Dotyczy on kwestii zaangażowania się pułków żołnierzy poszczególnych republik w walki dotyczące wewnętrznych sporów o władzę i wydanego w tej sprawie rozkazu: „O powyższym rozkazie pisze petersburski 'Dziennik Narodowy', że ‘chorąży Krylenko chce z żołnierzy nie-Rosjan uczynić niewolników, którzy za obce sprawy i na obcej ziemi mają krew przelewać" ${ }^{20}$. Na kolejnych stronach numeru czytelnik „IKC” znajdzie omówienie stosunku rosyjskich dyplomatów do spraw wewnętrznych Polski. Artykuł, zatytułowany Sprawy polskie w tajnych dokumentach rzqdu rosyjskiego, zawiera treść depeszy posła rosyjskiego w Londynie do p. Tereszczenki, w której przedstawiciel rosyjskiej dyplomacji udziela swojego poparcia dla polskich dążeń do samostanowienia, jednocześnie jednak wyraźnie odmawia zajęcia stanowiska i rekomendacji którejś z opcji politycznych.

Z grupą Dmowskiego moje osobiste stosunki poprawiły się i wciąż dążyłem do tego, aby trzymać się stanowiska, które Pan zajmuje. Z druga grupą sprawa stoi nieco inaczej. W tych dniach zwróciła się ona do mnie za pośrednictwem Zalewskiego, aby doręczyć Panu protest przeciwko działaniom grupy Dmowskiego. Odpowiedziałem, że ustaliłem z aprobaty ministerstwa zasadę niezłomną, iż poselstwo nie może bez sankcji Piotrogrodu być instancją pośredniczącą w partyjnych stosunkach politycznych ${ }^{21}$.

${ }^{18}$ Państwa centralne nie mogq zerwać z Rosjq. Prawo do stanowienia o sobie Polski, Litwy i Kurlandii musi być ściśle dochowane, „Ilustrowany Kurier Codzienny”, 1 stycznia 1918 roku, nr 1, s. 1.

${ }^{19}$ Ibidem, s. 2 i 3.

${ }^{20}$ Zatarg z bolszewikami o wojsko polskie, „IKC”, 3 stycznia 1918, nr 3, s. 2.

${ }^{21}$ Sprawy polskie $w$ tajnych dokumentach rzqdu rosyjskiego, „IKC”, 3 stycznia 1918, nr 3, s. 3. 
Następnie oświadcza, iż ministerstwo spraw zagranicznych doskonale zdaje sobie sprawę z istoty sporów obydwu partii. Wskazuje też na błędne, jego zdaniem, przekonanie przeciwników Dmowskiego, iż dąży on, z pomocą Anglii, Francji i Ameryki, do stworzenia państwa, które zdoła zająć miejsce Rosji jako europejskiego mocarstwa.

Przesadnych pretensji grupy Dmowskiego, o ile takie istotnie są, nie mogę traktować z obawą. Wydaje mi się niewątpliwym, że przeszedłszy obecny kryzys, Rosja zajmie w rodzinie narodów europejskich przynależne jej miejsce i wyższe niż poprzednio. Niepodległej zaś Polsce sądzone jest jeszcze przez wiele lat chwiać się pomiędzy dwiema orientacjami: wpływami Rosji z jednej, a austro-niemieckimi z drugiej ${ }^{22}$.

Omawianie faktycznej i domniemanej roli Rosji w kształtowaniu europejskiego ładu będzie zajmowało wiele miejsca na łamach „IKC”. Świadczą o tym liczne tytuły: Litwa zrywa wszelkie węzły z Rosja ${ }^{23}$, Zamianowanie posła bolszewickiego w Londynie, Międzynarodówka przeciw odrębnemu pokojowi Rosji, Zatarg Rosji z Rumunia, Odpowiedź Rumunii nie zadowala Rosji $i^{24}$. Niektóre teksty są utrzymane w sensacyjnym tonie, by wzbudzić zainteresowanie czytelnika. W numerze 6 „IKC” na pierwszej stronie zamieszczony został obszerny artykuł: Rokowania o pokój z Rosja zerwane. Układy rozbite z powodu Polski, Litwy $i$ Kurlandii ${ }^{25}$. Przyciaga on uwagę śródtytułami i fragmentami napisanymi pogrubioną czcionką, w rodzaju: „Rosja żąda przeniesienia rokowań do kraju neutralnego. Odrzucenie rosyjskich propozycji”, „Burzliwe posiedzenie komisji głównej”, „Kanclerz o zerwaniu rokowań”, „Nadzieja jeszcze nie zgasła”, „nie możemy się zgodzić na wniosek rosyjski”, „poleciliśmy przeto sekretarzowi stanu Kühlmannowi, by odrzucił tę propozycję”, zaś nieco bardziej wnikliwa lektura pozwala stwierdzić, iż obraz Rosji, wyłaniający się ze słów autora tekstu, pozwala ją postrzegać jako kraj z jednej strony pragnący dyktować warunki na podobieństwo Rosji carskiej, z drugiej zaś - niemający ku temu ani możliwości, ani praw. Ponadto, czytając tekst, jego odbiorca często odkrywa, iż wyeksponowany fragment w istocie dotyczy sprawy błahej, jak w przypadku słów ,,poleciliśmy przeto sekretarzowi stanu, Kühlmannowi, by odrzucił tę propozycję", gdzie sedno informacji stanowi wiadomość o problemach z połączeniami kolejowymi między Sztokholmem, dokąd Rosja proponowała przenieść rokowania z Brześcia, a stolicami państw biorących udział w rokowaniach ${ }^{26}$. Niemniej jednak cel, by przyciągnąć uwagę czytającego i skłonić go do zagłębienia się w treść artykułu, stał się w większym stopniu osiagalny dzięki temu niewyszukanemu chwytowi reklamowemu. Artykuł ma swój ciąg dalszy na stronie piątej numeru dziennika, gdzie rozpoczyna się od nagłówka: „Wiedeńskie sfery urzędowe wobec zerwania rokowań”.

Wątek Rosji jako kraju o nierealistycznych wyobrażeniach na temat własnych możliwości wywierania wpływu na ład europejski będzie pojawiał się wielokrotnie w treściach artykułów „IKC”, stanowiąc istotny element całościowego obrazu wschodniego sąsiada Polski. Na przykład w tekście Czy Rosja szczerze pragnie pokoju ${ }^{27}$ została poruszona kwestia przeniesienia rokowań z Brześcia. Odpowiedzialnością za opóźnienie rozmów

\footnotetext{
${ }^{22}$ Ibidem.

${ }^{23}$ „IKC”, 4 stycznia 1918, $\mathrm{nr} 4$.

${ }^{24}$ „IKC”, 5 stycznia 1918, nr 5.

${ }^{25}$ Rokowania o pokój z Rosja zerwane. Układy rozbite z powodu Polski, Litwy i Kurlandii, „IKC”, 6 stycznia 1918, nr 6, s. 1.

${ }^{26}$ Ibidem.

${ }^{27}$ Czy Rosja szczerze pragnie pokoju, „IKC”, 12 stycznia 1918, nr 12, s. 1.
} 
i znalezienie zadowalającego wszystkich konsensusu obarcza się Rosję. Wyłania się tutaj jej obraz jako kraju wysuwającego żądania o niezupełnie jasnych motywach, opóźniającego pomyślny wynik rokowań. W artykule przytoczono słowa hrabiego Czernina:

Czwór-przymierze (...) jest zgodne co do tego, aby rokowania na podstawie przez sekretarza stanu i przeze mnie przedstawionej i omówionej doprowadzić do końca. Jeśli panowie strony rosyjskiej nie są ożywieni podobnymi intencjami, to sprawy pójdą swym koniecznym biegiem, lecz odpowiedzialność za dalszą wojnę spadnie wtedy wyłącznie na rosyjską delegację ${ }^{28}$.

W świetle powyższych sformułowań, Rosja jawi się nie tylko jako potencjalny ,wichrzyciel”, lecz również jako kraj, który nie ma wpływu na ostateczny wynik konferencji. Sam tytuł artykułu skłania czytelnika do podania w wątpliwość intencji Rosji w kwestiach związanych z zakończeniem wojny.

Problem określenia roli Rosji w rokowaniach pokojowych nierozerwalnie wiąże się z pytaniem o istotę jej ustroju politycznego, charakter bolszewizmu. Za pośrednictwem zamieszczonego na pierwszej stronie artykułu Zjednoczona Polska programem bolszewików ${ }^{29}$ czytelnik „IKC” ma okazję zapoznać się z oświadczeniem bolszewickiej gazety „Izwiestija”, w której zwięźle, lecz dosadnie został skomentowany dotychczasowy przebieg obrad w Brześciu.

Obrona jedności Polski w czasie rokowań pokojowych (...) stanowi zadanie nie tylko rosyjskiej demokracji rewolucyjnej, lecz w większym jeszcze stopniu proletariatu niemieckiego i austriackiego, gdyż Galicja i zabór pruski są w rękach wewnętrznych wrogów proletariatu tych państw - imperialistów niemieckich i austriackich ${ }^{30}$.

Autor artykułu polskiej gazety nie pozostawia jednak bez komentarza przytoczonych słów. Zarzuca bolszewikom całkowitą nieświadomość dążeń proletariatu niemieckiego i austriackiego, kończąc wywód konkluzją, iż Polska nie będzie mogła liczyć na poparcie narodowych postulatów również z tej strony. Wśród mrocznych rysów portretu bolszewickiej Rosji coraz wyraźniej uwidaczniają się takie jej elementy, jak brak stabilności rządu. $\mathrm{W}$ miare jak namysł nad istotą bolszewizmu będzie znajdował swoje odzwierciedlenie w narastającej liczebności artykułów w „IKC”, zauważymy wyłanianie się kolejnego wzoru następujących po sobie jakości: niestabilność - chaos - żądza krwi - terror. Każdy jego element wchłania treści semantyczne poprzedniego członu i potęguje je, poprzez dodanie jednej cechy, wyrażonej, na przykład, w opisie rozprzężenia w armii, w bezkarnym plądrowaniu prywatnych majątków i sklepów, we wszechogarniającym głodzie.

Obraz bolszewickiej Rosji jako królestwa chaosu został nakreślony, między innymi, w artykułach z pierwszych stron „IKC”: Konflikt 'czerwonej gwardii'z wojskiem. Z chaosu wewnętrznego Rosji ${ }^{31}$, W Moskwie krew się leje ${ }^{32}$, Krwawe walki w Petersburgu ${ }^{33}$, Wysadzenie w powietrze rzqdu bolszewickiego w Moskwie ${ }^{34}$, Front rosyjski bez armii ${ }^{35}$.

\footnotetext{
${ }^{28}$ Ibidem.

${ }^{29}$ Zjednoczona Polska programem bolszewików, „IKC”, 13 stycznia 1918, nr 13, s. 1.

${ }^{30}$ Ibidem.

${ }^{31}$ Konflikt ,, czerwonej gwardii” $z$ wojskiem. Z chaosu wewnętrznego Rosji, „IKC”, 14 stycznia 1918, nr 14, s. 1.

${ }^{32}$ W Moskwie krew się leje, „IKC”, 24 stycznia 1918, nr 24, s. 3.

${ }^{33}$ Krwawe walki w Petersburgu, ,IKC”, 23 stycznia 1918, nr 23, s. 6.

${ }^{34}$ Wysadzenie w powietrze rzq̨u bolszewickiego w Moskwie, „IKC”, 1 stycznia 1918, nr 31, s. 2.

${ }^{35}$ Front rosyjski bez armii, ,IKC”, 24 stycznia 1918, nr 24.
} 
Próby określenia istoty bolszewizmu kierują autorów artykułów do poszukiwania wzorów w przeszłości Rosji, z czasów carskich. Wykorzystanie istniejącego już wcześniej kodu, by sprawdzić jego dopasowanie do aktualnej sytuacji i umieścić złożone i dynamiczne zjawiska $w$ ramach posiadanej struktury poznawczej to mechanizm obecny w stereotypach. W przypadku namysłu nad bolszewizmem jest on wyraźnie widoczny w takich artykułach, jak: Bolszewicy postapili z konstytuanta jak car z Duma ${ }^{36}$ czy Pomordowani carowie ${ }^{37}$.

Wieść o śmierci cara Mikołaja II, do której przygotowywały nas poprzednio już kilkakrotnie krążące pogłoski niestwierdzone, żywo stawia nam przed oczy fakt, że większość rosyjskich monarchów nie umierała śmiercią naturalną - że mord był tam rzeczą nieomal powszednią ${ }^{38}$.

Odwołanie do upadku caratu pozwala autorowi artykułu Zmierzch bolszewizmu wysunąc przypuszczenie, że bolszewizm także upadnie, jako system opierający się na tych samych co carat mechanizmach rządzenia.

Jakimż więc sposobem doszli bolszewicy do władzy. Takim samym aktem przemocy, na jakim opierały się rządy carskie. (...) Tyranię carskich rządów zastąpiła tyrania jeszcze bardziej barbarzyńska, bo tyrania upojonych krwią żołdaków. Dawniej nieograniczoną władzę posiadał tylko car - bolszewicką Rosję dławią krocie nieograniczonych a okrutnych tyranów ${ }^{39}$.

Nawiązanie do znanych wzorów kulturowych, by wytłumaczyć zachodzące aktualnie procesy i podpowiedzieć kierunek interpretacji wydarzeń poprzez podsunięcie łatwych, schematycznych skojarzeń, znajdziemy też w artykule Zbieranie ziem „,rosyjskich”"40, gdzie autor pisze:

Jest to odradzanie się z gruzów bolszewizmu rosyjskiej idei państwowej, która w pierwszych latach po wybuchu wojny przybrała skrajnie imperialistyczną formę pod hasłem tzw. zbierania ziemi rosyjskiej, obecnie zaś odżywa z wolna, ale widocznie, jako tendencja, zmierzająca do wytworzenia reakcyjnego procesu całkowania państwowego organizmu Rosji ${ }^{41}$.

Podejmując wątek działań bolszewików, mających na celu centralizację władzy i podporządkowanie republik peryferyjnych stołecznym organom, autor odwołuje się do historycznego wydarzenia, mającego miejsce w czasach Iwana IV Groźnego - cara, który swoją politykę podboju i tworzenia Rusi Moskiewskiej określił mianem „zbierania ziem ruskich" ${ }^{42}$. Podkreślając fakt, iż nawet w republikach dużą rolę odgrywa rosyjski element nacjonalistyczny, autor artykułu ucieka się do metafory, by pobudzić emocje czytelnika: przeciwstawia „królewską” Polskę - nagiej Rosji bolszewickiej:

\footnotetext{
${ }^{36}$ Bolszewicy postapili z konstytuanta jak car z Duma, „IKC”, 23 stycznia 1918 roku, nr 23, s. 6.

${ }^{37}$ Pomordowani carowie, „IKC”, 25 lipca 1918, nr 109, s. 3.

${ }^{38}$ Ibidem.

${ }^{39}$ Zmierzch bolszewizmu, „IKC”, 30 czerwca 1918, nr 84, s. 2.

${ }^{40}$ Zbieranie ziem ,,rosyjskich”, „IKC”, 30 lipca 1918, nr 114, s. 3.

${ }^{41}$ Ibidem.

${ }^{42}$ Por. J. Kucharzewski, Od białego do czerwonego caratu, Gdańsk 1990.
} 
Z królewskiego płaszcza naszej ziemi, z szerokiego koła promieniowania naszej myśli w przeszłość i teraźniejszość, rad by niejeden parweniusz i dziwaczny nowotwór państwowy uszczknąć jak najwięcej gwoli pokrycia własnej, historycznej nagości ${ }^{43}$.

„Polska” jako pojęcie mieszczące w sobie takie semantyczne jakości, jak porządek, prawo, cywilizacja, światło zostanie wielokrotnie przeciwstawiona „Rosji”, skojarzonej z chaosem, barbarzyństwem, nieokiełznaną ekspansywnością.

Z artykułu na pierwszej stronie 41 numeru „IKC”, zatytułowanego Warszawa o gen. Muśnickim $^{44}$, wyłania się obraz polskiego wojska jako narzędzia porządkowania przestrzeni chaosu i stawiania granicy jego rozpowszechnianiu się: „Faktem jest, że na widowni chaosu rosyjskiego wystąpił czynnik nowy - polski, wyróżniający się ładem, śmiałością i siłą" ${ }^{45}$.

Autor artykułu eksponuje wątek jedności narodowej, poczucie polskości, które nie uległo zatarciu pomimo oddalenia od ojczystej ziemi, wśród obcego żywiołu, począwszy od śródtytułu: „Nic nie starło z nich polskości”, aż po słowa:

Tysiączne rzesze polskich kmieciów, robotników i polskiej inteligencji (...) dają dzisiaj czynem swym wspaniałe świadectwo jedności narodowej. Nie starły z nich polskości trzy lata tułaczki na obczyźnie, nie zabiły ducha klęski niedołężnego dowództwa, nie zdemoralizowała anarchia rewolucji, która przemieniła w dzicz armie milionowe ${ }^{46}$.

Wnikliwa analiza treści pozwala odnaleźć zakodowaną triadę: Bóg - Honor - Ojczyzna. Fragment wieńczy błogosławieństwo: „Szczęść Wam, Boże”, zaś kolejny akapit, wydzielony śródtytułem „O Polską wolność” zawiera odniesienia do wartości, na których straży stoi polskie wojsko: wolność, prawo, porządek.

Rzecz zrozumiała, że dusza nam się wyrywa do tych choragwi polskich, rozwiniętych niezależnie i śmiało, i niosących na sobie nieśmiertelny znak orła białego na czerwonym polu jako znak wolności i prawa; że dumni jesteśmy z tego, iż właśnie w obronie prawa te pułki polskie idą naprzód, przeciwstawiając się anarchii i zniszczeniu ${ }^{47}$.

To kolejna opozycja binarna, którą należy odczytać jako mechanizm kształtowania i potwierdzania tożsamości narodowej za pomocą przeciwstawienia zbiorów rozłącznych cech, kodowanych jako „my” - „oni”. W tym przypadku zwykły żołnierz jest traktowany jako reprezentant polskości w jej najczystszej formie. W czasach caratu polska tożsamość narodowa kształtowała się i krzepła poprzez walkę narodowowyzwoleńczą. Duma, płynąca z pamięci o bohaterskich zrywach, jest narzędziem podtrzymywania ciągłości historycznej, odnajdywania korzeni oraz odwoływania się do fundamentów, na których można budować Polskę. Ton artykułu, styl budowania wypowiedzi oraz eksponowana symbolika pozwalają wysnuć wniosek o głębokim, działającym na podświadomość przekazie, a jednak czytelnym dla Polaków: w przeciwieństwie do bolszewickiej Rosji, rodząca się Polska nie jest państwem wyłaniającym się ex nihilo, lecz ma swoje tradycje.

\footnotetext{
${ }^{43}$ Zbieranie ziem rosyjskich, „IKC”, 30 lipca 1918, nr 114, s. 4.

${ }^{44}$ Warszawa o gen. Muśnickim, 10 lutego 1918, nr 41, s. 1.

45 Ibidem.

${ }^{46}$ Ibidem.

${ }^{47}$ Ibidem.
} 
Rzecz zrozumiała, że musiały nam serca zabić gorąco na wieść o tym, iż krew polska znów obfitym tryska strumieniem, (...) tam, na wielkim historycznym szlaku do Smoleńska brzmi pieśn ułanów polskich, lśni szabla oficera polskiego i połyskuje bagnet żołnierza Polaka, jak wówczas ... przed laty i przed wiekami ${ }^{48}$.

Artykuły zamieszczane na łamach „IKC”, dotyczące polskich żołnierzy w Rosji bolszewickiej koncentrują się wokół dwóch wątków tematycznych: siły polskiego oręża oraz działań ze strony rosyjskiej, mających na celu wymordowanie Polaków lub wykorzystanie ich do własnych celów. Jako egzemplifikację dokonanych obserwacji przytoczymy przykłady dwóch artykułów: Bolszewicy przeciw oddziałom polskim. Zamordowanie komendanta pulku polskiego ${ }^{49}$ oraz Wojna polsko-bolszewicka ${ }^{50}$. Wątek przewodni pierwszego artykułu to dążenia bolszewików do wciągnięcia polskich wojsk w walki wewnętrzne. Tekst zawiera cytaty z „Gazety Polskiej”, wychodzącej w Moskwie oraz „Dziennika Narodowego", wydawanego w Petersburgu. Są one utrzymane w tonie wzajemnych pogróżek i demonstracji siły: rosyjski generał Krylenko pisze do swojego podwładnego, Miasnikowa: „Wobec licznych znowu nadsyłanych zażaleń na postępowanie legionów polskich zastosujcie zarządzenia. Nie liczcie się nadal z tymi panami" "51; Polacy odpowiadają jednoznacznie:

Bolszewicy nie powinni spodziewać się, aby im się udało izolować korpus polski od społeczeństwa. Pan Krylenko z gestem mocarza wypowiada wielkie słowa: nie ceremoniować się z Polakami. Ale czy pamięta o tym, że Polacy mogliby też nie ceremoniować się z panem Krylenko, który bynajmniej wodzem potężnej i natchnionej duchem armii nie jest ${ }^{52}$.

Z kolei w artykule Wojna polsko-bolszewicka zostały poruszone dwie kwestie: zajęcie Orszy oraz sąsiednich garnizonów rosyjskich przez wojsko polskie oraz aresztowanie polskiego Naczelnego Komitetu Wojskowego. Informacja o militarnym sukcesie polskich oddziałów: „Polscy legioniści obsadzili dworzec w Orszy (gubernia mohylewska) i rozbroili rosyjski garnizon. Opanowali oni także dworce kolejowe na północ i na południe od Orszy, przy czym rozbroili rosyjskie straże" 53 , nie bez przyczyny sąsiaduje z wiadomością o bezprawnym aresztowaniu oficerów: „Dziś dokonano w Moskwie szeregu aresztowań wśród wojskowych Polaków. Aresztowanym nie przedstawiono żadnego oskarżenia, nie dokonywano rewizji, ani nie zabierano żadnych dokumentów, aresztowano ich bez żadnych przyczyn" 54 . Takie zestawienie ma budzić oburzenie postępkiem Rosjan, a jednocześnie pokazywać siłę Polaków.

Począwszy od czerwca 1918 roku, artykuły dotyczące Rosji w „IKC” coraz więcej miejsca poświęcają bolszewizmowi jako sile destrukcyjnej. Z biegiem czasu aspekt emocjonalny bierze górę nad stroną informacyjną, zaś w tekstach można zauważyć dwa współzależne wątki: bolszewizm jako siła w najwyższym stopniu niszcząca oraz przekonanie

\footnotetext{
${ }^{48}$ Ibidem.

${ }^{49}$ Bolszewicy przeciw oddziałom polskim. Zamordowanie komendanta pułku polskiego, IKC”, 22 stycznia

${ }^{50}$ Wojna polsko-bolszewicka, ,IKC”, 30 stycznia 1918, nr 30, s. 1.

${ }^{51}$ Bolszewicy przeciw oddziałom polskim, „IKC”, 22 stycznia 1918, nr 22, s. 3.

${ }^{52}$ Ibidem.

${ }^{53}$ Wojna polsko-bolszewicka, „IKC”, 30 stycznia 1918, nr 30, s. 1.

${ }^{54}$ Ibidem.
} 1918 , nr 22, s. 3. 
o jego nietrwałości. Towarzyszą im artykuły o nadciagającej kontrrewolucji, bolszewickiej propagandzie w Polsce, bezprawiu panującym w Rosji. „IKC” zamieszcza też kilka tekstów, w których myślą przewodnią jest życie kulturalne, niemniej jednak i na nich kładzie się cieniem bolszewizm.

Autor artykułu Raj bolszewickiego państwa przyszłości dzieli się z czytelnikami wizją rzeczywistości, jaka nastanie, gdy bolszewicy umocnią się u władzy:

W nocy na 4 lutego splądrowano pałac w. ks. Marii Pawłowiczowej. Zrabowano wszystkie przedmioty wartościowe. Tej samej nocy uzbrojona banda złożona z 500 ludzi, obrabowała 15 sklepów jubilerskich, 17 sklepów z ubraniami i 4 apteki. (...) Zabito przy tym 120 osób, a jeszcze więcej raniono ${ }^{55}$.

Skutki ich działań są widoczne na każdym kroku: w rubryce „Co dzień niesie”, w artykule Życie w stolicy Rosji czytamy:

W mieście brak jakiegokolwiek bezpieczeństwa, nie ma wcale policji, nikt wychodząc z domu nie wie, czy wróci cały, a kładąc się spać, czy się obudzi. Wszyscy żyją z dnia na dzień, wyczekując jak zbawienia obalenia bolszewików, w które wszyscy wierzą święcie ${ }^{56}$.

Istota rządów bolszewików została w jednym z numerów „IKC” określona mianem „chamiokracji” ${ }^{57}$, zaś w odniesieniu do tworzonego przez nie państwa autorzy artykułów kilkakrotnie użyli słowa „nowotwory”.

Niełatwo jest się dziś zorientować w mnogości nowotworów państwowych, które powyrastały na gruzach carskiej Rosji, które wciąż jeszcze wyrastają, by trwać lub też zniknąć, jak efemerydy, i miejsce dla innych uczynić ${ }^{58}$.

W artykułach pojawiają się również mgliste wizje Rosji, jaka narodzi się po upadku bolszewizmu. Jawi się ona jako kraj podobny do Polski pod względem wartości i mentalności. Przesłanki do wyciąnnięcia takiego wniosku znajdziemy w artykule Rosja zrozumiała, że ,upór polski” jest bohaterstwem, a ,zbrodnia” szlachetnościq.

Z potu krwawej mgławicy, unoszącej się nad pobojowiskami bolszewickiej Rosji słabe tylko dochodzą odgłosy budzącego się uświadomienia wśród narodu rosyjskiego. Nie ulega jednak wątpliwości, że z dzisiejszego chaosu prędzej czy później musi się zrodzić nowa, wyswobodzona z obłędu bolszewickiego Rosja ${ }^{59}$.

Podobny wątek, mówiący o istnieniu w Rosji elementów przeciwstawnych do bolszewickiego chaosu i żądzy krwi, stanowi myśl przewodnią artykułu: Głos ginacej Rosji, z podtytułem ,Jasny i smętny duch Mickiewicza”:

Wszystko, co przeszkadza pochodowi postępu, samo się niszczy. Kiedy w dawnej Turcji sułtan chciał usunąć ze świata wezyra, który się jemu przestał podobać, posyłał mu sznur przez

${ }^{55}$ Raj bolszewickiego państwa przyszłości, „IKC”, 8 lutego 1918, nr 39, s. 6.

${ }^{56}$ Życie w stolicy Rosji, „IKC”, 9 lipca 1918, nr 93, s. 3.

${ }^{57}$ Petersburg pod rzqdami ,,chamiokratów”, „IKC”, 15 sierpnia 1918, nr 130, s. 3.

${ }^{58} \mathrm{Na}$ gruzach caratu, „IKC”, 14 lipca 1918, nr 98, s. 2.

${ }^{59}$ Rosja zrozumiała, że 'upór polski 'jest bohaterstwem, a 'zbrodnia' szlachetnościa, „IKC”, 30 sierpnia 1918 , nr 145, s. 3. 
niewolnika i wezyr natychmiast zarzucał sobie stryczek na szyję. Tym złowieszczym niemym bolszewikiem dla Rosji byli bolszewicy. Ich ręce podsunęły krajowi sznur i Rosja samobójczo zginęła $^{60}$.

\section{Podsumowanie}

W roku 1918 Polska posiada utrwalony kod kulturowy dotyczący Rosji carskiej: to mocarstwo zaborcze, którego zakusy na terytorium Polski zakończyły się sukcesem ponad sto lat wcześniej, będące rywalem ówczesnych potęg europejskich i jednym z graczy o terytorium Polski wraz z jego zasobami; państwo rządzone przez despotę w oparciu o azjatyckie tradycje sprawowania władzy. Wyłaniająca się po rewolucji lutowej bolszewicka Rosja stanowiła kontynuatorkę poprzedniego reżymu, a jednocześnie dodawała do niego nowe jakości. Kontynuację autorzy artykułów „IKC” widzieli w sposobie rozprawiania się z ideowymi przeciwnikami, stosowaniu terroru jako skutecznego narzędzia władzy, stylu zagarniania nowych terytoriów. Negocjacje w Brześciu Litewskim stanowiły potwierdzenie, że Rosja nadal jest liczącym się graczem na arenie europejskiej, równocześnie jednak odsłoniły słabość jej władz politycznych, wynikającą z faktu, że bolszewizm nie zdołał jeszcze umocnić swoich pozycji. Brak silnej władzy centralnej stworzył sprzyjające warunki do dezintegracji życia na ziemiach dawnego imperium rosyjskiego we wszystkich jego aspektach: politycznym, społecznym, gospodarczym. Określająca się wcześniej poprzez walkę narodowowyzwoleńczą Polska, obecnie musiała poszukać innych punktów odniesienia do samoidentyfikacji. Tym bardziej, że odradzała się jako państwo, a to wymagało stabilnych fundamentów tożsamości. Jej umacnianie odbywało się za pomocą przeciwstawienia rodzącej się Polski bolszewickiej Rosji. Do zbiorów przeciwstawnych cechy: „my” - „oni” weszły takie elementy jak: prawość, duma, patriotyzm, waleczność, honor i porządek po stronie Polski, a bezprawie, „,chamiokracja”, żądza krwi, grabież i chaos po stronie Rosji bolszewickiej. Próba ujęcia w kod kulturowy bolszewizmu była odpowiedzią na pytanie o to, z czym Polska będzie musiała się mierzyć nie tylko w sensie politycznym, lecz także - kulturowym. W roku 1918 na żadne z tych pytań nie dało się udzielić ostatecznej odpowiedzi, dlatego definitywnie na obraz Rosji złożyły się znane już kody Rosji carskiej, elementy bolszewizmu jako zwyrodnienia i odsłonięcia słabości poprzedniego ustroju oraz przekonanie, znajdujące się na granicy gorącego pragnienia i wiary, że bolszewizm musi upaść. Rok 1918 czytelnicy „IKC” żegnali z przekonaniem, że Polska jako kraj cywilizowany, stojący na straży porządku i prawa, ma za zadanie przeciwstawienie się rewolucyjnemu chaosowi bolszewickiej Rosji. Oczekiwano na wodza, który się pojawił. Był to Józef Piłsudski. Wokół niego zbudowano tożsamość pierwszych lat II Rzeczypospolitej.

\section{Perspektywy badawcze}

Dokonany przegląd treści artykułów prasowych odsłania dalsze kierunki badań, z perspektywy mechanizmów kultury. Przede wszystkim warto byłoby poddać analizie

\footnotetext{
${ }^{60}$ Głos ginqcej Rosji, „IKC”, 19 sierpnia 1918, nr 134, s. 4
} 
zawartość innych krakowskich dzienników w roku 1918 i stwierdzić, jaki obraz Rosji wyłania się z ich artykułów, jakich narzędzi kodowania kultury się używa oraz w jaki sposób reprezentowana postawa ideowa czy afiliacja partyjna wpływają na prezentację wydarzeń. Drugi, interesujący kierunek badań, to przeanalizowanie dzienników z głównych ośrodków pozostałych zaborów: rosyjskiego i pruskiego, przy postawieniu tych samych pytań.

Wnioski mogłyby stanowić obiecujący punkt wyjścia do namysłu nad trwałością i/lub cyklicznością kodów kulturowych, poprzez porównanie wyników badań prasy z 1918 roku z treściami polskiej prasy w setną rocznicę odzyskania przez Polskę niepodległości - w roku 2018.

\section{Bibliografia}

Teksty źródłowe:

„Ilustrowany Kurier Codzienny” („IKC”), rok 1918, nr 1-266.

Opracowania:

Bloom W., Personal Identity, National Identity and International Relations, Cambridge 1990.

Bohun M., Goćkowski J. (red.), Zagadnienie rosyjskie. Myślenie o Rosji: oglady i obrazy spraw rosyjskich, Kraków 2000.

Brzoza Cz., Polityczna prasa krakowska 1918-1939, Kraków 1990.

Faryno J., Как проявить имидж соседа, [w:] Bobryk R., Faryno J. (red.), Polacy w oczach Rosjan - Rosjanie w oczach Polaków, Warszawa 2000, s. 389-390.

Gostyńska W. (oprac.), Dokumenty i materiały do historii stosunków polsko-radzieckich, t. 1, marzec 1917-listopad 1918, Warszawa 1962.

Jadacki J.J., Metodologia i semiotyka: idee - metody - problemy, Warszawa 2010.

Jankowska H., Jędruszczak T. (red.), Powstanie II Rzeczypospolitej. Wybór dokumentów 1886-1925, Warszawa 1981.

Lappo I., Profilowanie stereotypu Rosjanina w polskim kręgu językowo-kulturowym, „Etnolingwistyka", t. 14, Lublin 2002, s. 153-174.

de Lazari A., Katalog wzajemnych uprzedzeń Polaków i Rosjan, Warszawa 2006.

Lisiak H., Obraz bolszewika w oczach Polaków w pierwszych latach odradzajacej się II Rzeczypospolitej (1918-1920), [w:] G. Kotlarski, M. Figura (red.), Oblicza Wschodu w kulturze polskiej, Poznań 1999, s. 383-394.

Myśliński J., Studia nad polska prasq społeczno-polityczna w Zachodniej Galicji 1905-1914, „Materiały i Studia do Historii Prasy i Czasopiśmiennictwa Polskiego”, z. 16, Warszawa 1970.

Pelczarski J., Niektóre fakty z historii koncernu „Ilustrowanego Kuriera Codziennego”, „Prasa Współczesna i Dawna”, nr 2, Kraków 1958.

Seniów J.M., Na drodze do niepodległości. Prasa krakowska wobec Legionów Polskich podczas I wojny światowej (1914-1918), Kraków 2004.

Seniów J.M., Prasa krakowska w czasie pierwszej wojny światowej (1914-1918), „Zeszyty Prasoznawcze", r. XLV, nr 3-4, Kraków 2002, s. 120-136.

Sosnowska D., Inna Galicja, Warszawa 2008.

Stobiecki R., Rosja i Rosjanie w polskiej myśli historycznej XIX i XX wieku, [w:] A. de Lazari (red.), Katalog wzajemnych uprzedzeń Polaków i Rosjan, Warszawa 2006, s. 159-202.

Zernack K., Polska i Rosja. Dwie drogi w dziejach Europy, A. Kopacki (przeł.), Warszawa 2000.

Żyłko B., Semiotyka. Szkoła tartusko-moskiewska, Gdańsk 2009. 
Małgorzata Abassy, dr hab., prof. UJ - kulturoznawca i literaturoznawca, rusycystka i iranistka, kierownik Zakładu Nowożytnej Kultury Rosyjskiej i Teorii Systemów Kulturowych w Instytucie Rosji i Europy Wschodniej na Wydziale Studiów Międzynarodowych i Politycznych Uniwersytetu Jagiellońskiego.

Autorka czterech monografii: Inteligencja a kultura. O problemach samoidentyfikacji dziewiętnastowiecznej inteligencji rosyjskiej (2008), Irańska inteligencja i Rewolucja Konstytucyjna (19051911) (2010), Kultura wobec postępu i modernizacji. Rosja i Iran w perspektywie porównawczej (2013), Russian Mason - Nicolas Novikov (2015) oraz kilkudziesięciu artykułów, m.in. Irańska ropa naftowa: znaczenie strategiczne i symboliczne (2018), The Conception of Culture, Values and Identity of Iran in Shaykh Fazlallah Nuri's Writings (2017), Syberia w pamięci zestańców i ich dzieci. Studium przypadku rodziny Żukowskich (2017), Политические ценности демократии в России, Беларуси и Польше: сравнительный анализ (2016).

Obszary zainteresowań badawczych to: kulturowe uwarunkowania odmienności Rosji i krajów islamskich od Zachodu, stosunki rosyjsko-irańskie i polsko-rosyjskie na fundamencie kultury, literatura piękna i publicystyka jako narzędzia kształtowania świadomości narodowej oraz źródło wiedzy o historii i mentalności narodów.

malgorzata.abassy@uj.edu.pl

ORCID: 0000-0002-9294-6156 